\title{
Meta Analisis Komparasi Keefektifan Model Pembelajaran Kooperatif Tipe Jigsaw Dan Tsts (Two Stay Two Stray) Terhadap Kemampuan Berpikir Kritis Pada Pembelajaran Matematika Siswa Sekolah Dasar
}

\section{Bunga Leniati ${ }^{1 *}$, Endang Indarini ${ }^{2}$}

\author{
12 Universitas Kristen Satya Wacana, Salatiga, Indonesia \\ *e-mail: bungaleniati99@gmail.com
}

\begin{abstract}
Abstrak
Masih banyaknya siswa yang kurang fokus atau bahkan tidak fokus dalam mengikuti kegiatan pembelajaran dan kurang memiliki rasa ingin tahu yang tinggi, sehingga berdampak pada kemampuan berpikir kritis yang rendah. Penelitian ini bertujuan untuk menganalisis perbedaan komparasi keefektifan model pembelajaran kooperatif tipe Jigsaw dan Two Stay Two Stray (TSTS) terhadap kemampuan berpikir kritis pada pembelajaran matematika. Subjek penelitian ini adalah kumpulan artikel pembelajaran Jigsaw dan Two Stay Two Stray (TSTS) terhadap kemampuan berpikir kritis siswa, berjumlah 12 artikel publikasi ilmiah. Hasil analisis menyebutkan bahwa hipotesis dengan menggunakan uji Ancova menggunakan Univariate yang menunjukkan nilai signifikasi sebesar 0,038 yang artinya lebih kecil dari 0,05 $(0,038<0,05)$. Hasil uji Ancova membuktikan fhitung < ftabel yaitu 5,918 > 4,26 dan signifikasinya 0,038< 0,05 yang membuktikan bahwa Ho ditolak dan Ha diterima. Dari hasil tersebut terbukt bahwa terdapat perbedaan yang signifikan antara penggunaan model pembelajaran Jigsaw dan Two Stay Two Stray (TSTS). Hasil analisis menggunakan uji Ancova untuk mengetahui effect size sebesar 0,683 dengan nilai Sig. 0,006. Hal ini menunjukkan bahwa model pembelajaran Jigsaw dan Two Stay Two Stray (TSTS) memberikan pengaruh tergolong besar terhadap kemampuan berpikir kritis pada pembelajaran matematika siswa sekolah dasar. Implikasi penelitian ini model pembelajaran Jigsaw dan Two Stay Two Stray dapat meningkatkan kemampuan berpikir kritis pada siswa.
\end{abstract}

Kata kunci: jigsaw, two stay two stray (tsts), kemampuan berpikir kritis

\begin{abstract}
There are still many students who do not focus on participating in learning activities and do not have high curiosity, so that it has an impact on their low critical thinking skills. This study aims to analyze the comparative difference between the effectiveness of the Jigsaw and Two Stay Two Stray (TSTS) cooperative learning models on critical thinking skills in mathematics learning. The subject of this research is a collection of Jigsaw and Two Stay Two Stray (TSTS) learning articles on students' critical thinking skills, totaling 12 scientific publication articles. The results of the analysis state that the hypothesis using the Ancova test uses Univariate which shows a significance value of 0.038 which means less than $0.05(0.038<0.05)$. The Ancova test results prove that the $f$-count $<$-tabel is $5.918>4.26$ and the significance is 0.038 $<0.05$ which proves that $\mathrm{Ho}$ is rejected and $\mathrm{Ha}$ is accepted. From these results it is evident that there is a significant difference between the use of the Jigsaw and Two Stay Two Stray (TSTS) learning models. The results of the analysis used the Ancova test to determine the effect size of 0.683 with a Sig. 0.006. This shows that the Jigsaw and Two Stay Two Stray (TSTS) learning models have a significant influence on critical thinking skills in elementary school students' mathematics learning. The implication of this research is that the Jigsaw and Two Stay Two Stray learning model can improve students' critical thinking skills.
\end{abstract}

Keywords: jigsaw, two stay two stray (tsts), critical thinking skills

\footnotetext{
${ }^{*}$ Corresponding author.

Received 30 Januari 2021; Accepted 1 Maret 2021; Available online 8 April 2021 (C) 2021 MI All Rights Reserved
} 


\section{Pendahuluan}

Pendidikan adalah cara dalam memberikan pengetahuan, wawasan, dan keahlian kepada individu. Pendidikan juga menghendaki agar dapat mengembangkan potensi peserta didik menjadi manusia yang aktif dalam pembelajaran, karena sukses tidaknya pembelajaran yang dilaksanakan oleh guru bergantung pada sikap, tingkah laku, dan pola pikir siswa (Fitri, 2016; Mawarni \& Muhtadi, 2017). Karena hal tersebut, pembelajaran memiliki tujuan yang sangat penting untuk mensukseskan pendidikan di Indonesia, salah satunya pendidikan di Sekolah Dasar (SD). Terdapat tiga kemampuan dasar yang harus diajarkan di Sekolah Dasar/Madrasah Ibtidaiyah (SD/MI) dalam K13 dilakukan dengan pendekatan tematik terpadu, kecuali pelajaran matematika dan PJOK sebagai mata pelajaran yang berdiri sendiri untuk kelas tinggi. Hal ini terjadi karena materi dalam muatan pelajaran matematika pada buku tematik K13 dirasa kurang mendalam (Fatqurohman, 2010; Hurianti \& Tastra, 2018). Hal ini bisa dibuktikan dengan kemampuan berpikir siswa yang kurang kreatif sehingga mempengaruhi hasil belajar matematika siswa.

Matematika merupakan salah satu mata pelajaran yang penting dalam dunia pendidikan, karena mata pelajaran matematika merupakan salah satu pengetahuan yang paling bermanfaat bagi kehidupan (Ariawan \& Pratiwi, 2017; Mahendra, 2017). Tetapi, siswa masih memiliki prestasi rendah dalam pembelajaran matematika di Indonesia. Dalam data yang tertera di Programme for International Student Assesment (PISA) pada rentan antara tahun 2000-2018 menunjukkan bahwa peringkat matematika Indonesia berada diperingkat 72 dari 78 negara yang membuktikan bahwa Indonesia merupakan salah satu negara yang konsisten dengan peringkat hasil PISA terendah (Fuadi, Robbia, Jamaluddin, \& Jufri, 2020; Sariani, 2020). Memiliki skor PISA yang stagnan dalam kurun waktu 10-15 tahun terakhir, namun selisih skor dengan rata-rata skor OECD sudah sedikit meningkat, seperti terlihat pada grafik berikut ini.

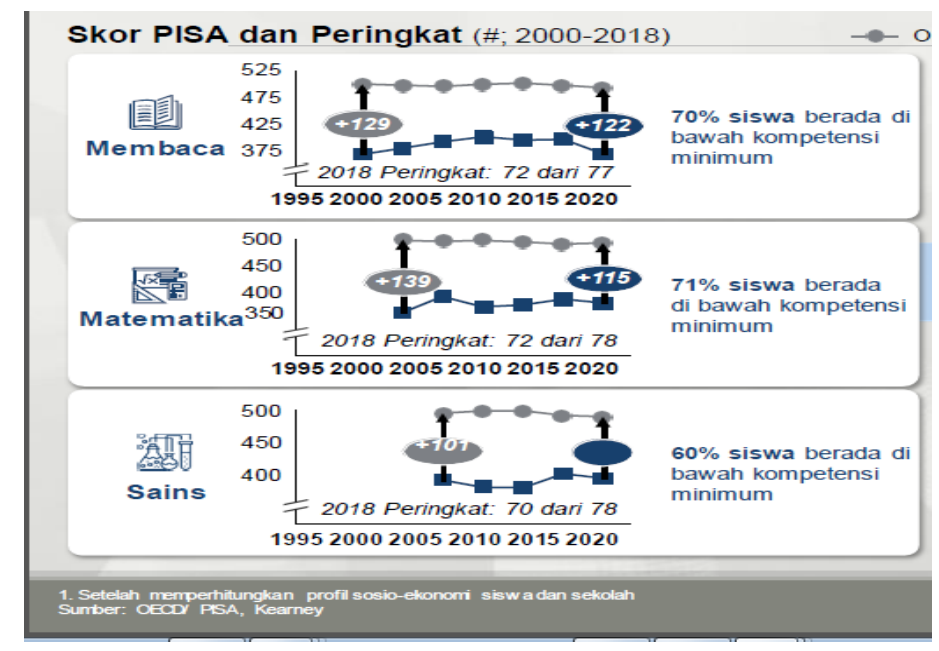

Gambar 1. Skor PISA

Pendidikan pada abad 21 menuntut siswa untuk lebih aktif dalam kegiatan pembelajaran dan guru dituntut untuk mengajar menggunakan model pembelajaran yang disarankan oleh kurikulum 2013 untuk memancing siswa supaya lebih aktif dalam mengikuti kegiatan pembelajaran (Lubis, 2018; Redhana, 2019). Tuntutan ini mengharuskan siswa untuk memiliki kemampuan 4C, meliputi Collaboration (memberikan kesempatan kepada siswa untuk bekerja dalam kelompok), Creative (siswa diharuskan berpikir kreatif dan tidak terpaku pada satu cara), Communication (adanya timbal balik antara guru dan siswa maupun sebaliknya), dan Critical Thinking and Problem Solving (menuntut siswa berpikir 
kritis dalam menanggapi situasi dan kondisi saat pembelajaran dan mampu memecahkan masalah) (Andrian \& Rusman, 2019; Yokhebed, 2019). Salah satu dari komponen 4C yang perlu dimiliki siswa yaitu kemampuan berpikir kritis. Kegiatan kemampuan berpikir kritis terdiri dari aktivitas merumuskan masalah, merencanakan strategi atau taktik dan merumuskan kesimpulan (Budiana, Sudana, \& Suwatra, 2013; Purwanti, 2015). Di sekolah dasar perlu adanya mengembangkan pola berpikir kritis siswa untuk menyiapkan kehidupan masa depan ketika menghadapi perkembangan zaman.

Upaya yang dapat dilakukan untuk meningkatkan kemampuan berpikir kritis siswa yaitu dengan pemberian kesempatan kepada siswa untuk membangun pengetahuannya secara aktif, artinya pengetahuan ditemukan, dibentuk, dan dikembangkan oleh siswa sendiri baik secara individu maupun kelompok dengan menggunakan model pembelajaran kooperatif. Model pembelajaran kooperatif adalah model pembelajaran yang menggunakan sistem pengelompokkan untuk mencapai tujuan pembelajaran yang telah dirumuskan (Dadri \& Putra, 2017; Witari, Putri, \& Rati, 2017). Tujuan penting dari pembelajaran kooperatif yaitu untuk mengajarkan kepada siswa keterampilan kerjasama dan kolaborasi (Dharsana \& Sidabutar, 2018). Model pembelajaran kooperatif ada beberapa tipe, diantaranya adalah tipe Jigsaw, merupakan model pembelajaran kooperatif dengan cara membagi siswa ke dalam kelompok-kelompok kecil yang terdiri dari 4-5 orang, kelompok tersebut nantinya akan disebut sebagai kelompok ahli dan kelompok asal (Sari, 2014; Wicaksono \& Corebima, 2015). Selain model pembelajaran kooperatif tipe Jigsaw ada juga tipe Two Stay Two Stray (TSTS) atau dua tinggal dua tamu, yang memberikan kesempatan kepada siswa untuk membagikan hasil dan mencari informasi dengan kelompok lainnya (Mulyantini, Suranata, \& Margunayasa, 2019; Nurmiyati \& Suyata, 2014). Dari dua model pembelajaran kooperatif tipe Jigsaw dan Two Stay Two Stray (TSTS) diasumsikan dapat meningkatkan kemampuan berpikir kritis siswa melalui hasil penelitian sebelumnya. Pada penelitian tindakan dan eksperimen dilakukan dengan melakukan treatment atau tindakan terhadap siswa, maka pada penelitian meta analisis menggunakan review jurnal penelitian sebelumnya untuk menentukan keefektifan dari penggunaan dua model pembelajaran.

Hasil penelitian yang mendukung penelitian ini yaitu penelitian yang dilakukan oleh Anwar (2018) menunjukkan bahwa nilai rata-rata posttest model pembelajaran Two Stay Two Stray (TSTS) lebih tinggi yaitu sebesar $44,32 \%$ sedangkan untuk nilai rata-rata posttest model Jigsaw sebesar $31,35 \%$. Keberhasilan model pembelajaran TSTS terhadap kemampuan berpikir kritis siswa dipengaruhi adanya keaktifan siswa dalam melaksanakan diskusi serta interaksi dengan kelompok lain melalui kegiatan stay dan stray. Hal ini sejalan dengan kelebihan yang dimiliki model pembelajaran Two Stay Two Stray (TSTS) yaitu berorientasi pada keaktifan siswa (Dharsana \& Sidabutar, 2018; Mulyantini et al., 2019). Melalui diskusi, klarifikasi, dan evaluasi ide dari orang lain dapat mengembangkan kemampuan berikir kritis.

Berdasarkan uraian latar belakang di atas, maka tujuan dan fokus penelitian ini yaitu untuk mengetahui ada tidaknya perbedaan komparasi keefektifan model pembelajaran kooperatif tipe Jigsaw dan Two Stay Two Stray (TSTS) terhadap kemampuan berpikir kritis pada pembelajaran matematika siswa Sekolah Dasar menggunakan metode penelitian meta analisis. Diharapkan model pembelajaran kooperatif tipe Jigsaw dan Two Stay Two Stray (TSTS) dapat membantu siswa dalam belajar sehingga dapat meningkatkan kemampuan berpikir kritis pada siswa.

\section{Metode}

Penelitian ini dilaksanakan menggunakan jenis penelitian meta analisis. Meta analisis merupakan teknik statistika dengan menggabungkan dua data maupun lebih dari penelitian sejenis untuk diperoleh data secara kuantitatif. Jika dilihat dari prosesnya, meta analisis merupakan studi yang bersifat observasional retrospektif, di dalam penelitiannya seorang peneliti membuat rekapitulasi data tanpa memanipulasi eksperimental. Yangmana dimensi effect size yang digabungkan dalam meta analisis harus sama dengan yang akan dilaporkan 
dalam artikel yang nantinya akan digabungkan. Meta analisis memiliki beberapa langkahlangkah peneitian, yaitu memformulasikan permasalahan penelitian, mengumpulkan bahan literatur melalui hasil penelitian yang sesuai dengan tujuan yang diinginkan, melakukan evaluasi terhadap penelitian untuk mencaru informasi, melakukan analisa dan interpretasi dari literatur dan terakhir menyajikan hasil meta analisis dalam bentuk tulisan. Desain yang digunakan dalam penelitian ini adalah merangkum, mereview, dan menganalisis beberapa penelitian yang menggunakan model pembelajaran Jigsaw dan Two Stay Two Stray (TSTS) terhadap peningkatan kemampuan berpikir kritis siswa pada pembelajaran matematika yang sudah diteliti sebelumnya. Penelitian meta analisis dapat dicari melalui jurnal online dan google scholar sebagai sumber yang akan dianalisis.

Teknik analisis data yang digunakan dalam penelitian meta analisis adalah dengan mencari artikel-artikel yang terdapat pada jurnal online dan google scholar sebagai sumber yang akan dianalisis. Dari hasil pencarian artikel ditemukan 12 artikel eksperimen dengan kategori yang digunakan dalam penelitian ini yaitu artikel yang dibuat oleh peneliti umum atau mahasiswa, artikel yang digunakan terbit 10 tahun terakhir yaitu tahun 2012-2021, artikel yang digunakan bertema model pembelajaran Jigsaw terhadap kemampuan berpikir kritis siswa, artikel yang digunakan bertema model pembelajaran TSTS (Two Stay Two Stray) terhadap kemampuan berpikir kritis siswa, sampel yang digunakan dalam penelitian ini merupakan jenjang pendidikan Sekolah Dasar (SD), lingkup wilayah penelitian yang digunakan adalah di kawasan Indonesia. Dari jurnal tersebut, kemudian dianalisis untuk melihat nilai pretest dan posttest yang akan digunakan untuk mengukur kemampuan berpikir kritis siswa sebelum dan sesudah diberikan treatment atau tindakan. Setelah mendapatkan hasil pretest dan posttest kemudian data tersebut diolah menggunakan SPSS 25 for windows untuk melihat hasil uji effect size. Sebelum melakukan uji effect size dilakukan uji normalitas, uji homogenitas, uji linearitas, dan uji ancova.

\section{Hasil dan Pembahasan}

Langkah awal yang dilakukan dalam penelitian ini yaitu menentukan masalah, kemudian melakukan penelusuran pencarian data penelitian melalui jurnal elektronik di google scholar dengan mengumpulkan 12 artikel yang relevan guna diambil datanya. Peneliti menemukan masing-masing 6 jurnal pada dua model pembelajaran yang diteliti. Model pembelajaran Jigsaw berjumlah 6 jurnal, berikut ini data skor pretest dan posttest yaitu:

Tabel 1. Presentase Peningkatan Kemampuan Berpikir Kritis Pembelajaran Matematik.a Dengan Model Pembelajaran Jigsaw

\begin{tabular}{ccccc}
\hline No. & Kode Data & \multicolumn{3}{c}{ Presentase (\%) } \\
\cline { 3 - 5 } & & Skor Pretest & Skor Postest & Peningkatan \\
\hline 1 & JG1 & 28,75 & 62,28 & 33,53 \\
2 & JG2 & 30,69 & 38,30 & 7,61 \\
3 & JG3 & 88 & 76 & 48 \\
4 & JG4 & 54,17 & 74,58 & 20,41 \\
5 & JG5 & 41,88 & 50,96 & 9,08 \\
6 & JG6 & 61,90 & 74,93 & 13,03 \\
\hline & Rata-rata & $\mathbf{4 2 , 5 6}$ & $\mathbf{6 4 , 5 0}$ & $\mathbf{2 1 , 9 4}$ \\
\hline
\end{tabular}

Berdasarkan pada tabel di atas, dapat diketahui bahwa model pembelajaran Jigsaw dapat meningkatkan kemampuan berpikir kritis pada pembelajaran matematika siswa sekolah dasar. Presentase rata-rata peningkatan kemampuan berpikir kritis pada pembelajaran matematika menggunakan model pembelajaran Jigsaw dari skor terendah sebesar $7,61 \%$ dan skor tertinggi sebesar $48 \%$ dengan rata-rata sebesar $21,94 \%$. Presentase rata-rata kemampuan berpikir kritis pada skor pretest dengan menggunakan model Jigsaw sebesar $42,56 \%$. Presentase rata-rata kemampuan berpikir kritis pada skor 
posttest dengan menggunakan model pembelajaran Jigsaw sebesar $64,50 \%$. Persentase rata-rata sebelum dan sesudah menggunakan model pembelajaran Jigsaw mengalami peningkatan sebesar 21,94\%. Model pembelajaran Two Stay Two Stray (TSTS) juga berjumlah 6 jurnal, berikut ini data skor pretest dan posttest yaitu:

Tabel 2. Presentase Peningkatan Kemampuan Berpikir Kritis Pembelajaran Matematika Dengan Model Pembelajaran TSTS (Two Stay Two Stray)

\begin{tabular}{ccccc}
\hline No. & Kode Data & \multicolumn{3}{c}{ Presentase (\%) } \\
\cline { 3 - 5 } & & Skor Pretest & Skor Postest & Peningkatan \\
\hline 1 & TS1 & 43,5 & 73,5 & 30 \\
2 & TS2 & 59,52 & 67,88 & 8,36 \\
3 & TS3 & 42,7 & 77,4 & 34,7 \\
4 & TS4 & 45,50 & 68,89 & 23,39 \\
5 & TS5 & 35,59 & 83,41 & 47,82 \\
6 & TS6 & 43,59 & 75,94 & 32,35 \\
\hline & Rata-rata & $\mathbf{4 5 , 0 6}$ & $\mathbf{7 4 , 5 0}$ & $\mathbf{2 9 , 4 3}$ \\
\hline
\end{tabular}

Berdasarkan pada tabel di atas, dapat diketahui bahwa model pembelajaran TSTS (Two Stay Two Stray) dapat meningkatkan kemampuan berpikir kritis pada pembelajaran matematika siswa sekolah dasar. Presentase rata-rata peningkatan kemampuan berpikir kritis pada pembelajaran matematika dengan menggunakan model pembelajaran TSTS (Two Stay Two Stray) dari skor terendah sebesar 8,36\% dan skor tertinggi sebesar 47,82\% dengan rata-rata sebesar $29,43 \%$. Presentase rata-rata kemampuan berpikir kritis pada skor pretest dengan menggunakan model pembelajaran TSTS (Two Stay Two Stray) sebesar 45,06\%. Presentase rata-rata kemampuan berpikir kritis pada skor posttest dengan menggunakan model pembelajaran TSTS (Two Stay Two Stray) sebesar 74,50\%. Persentase rata-rata sebelum dan sesudah menggunakan model pembelajaran TSTS (Two Stay Two Stray) mengalami peningkatan sebesar $29,43 \%$.

Uji Ancova dilakukan untuk mengetahui ada tidaknya perbedaan yang signifikan antara penggunaan model pembelajaran Jigsaw dan Two Stay Two Stray (TSTS) terhadap kemampuan berpikir kritis pada pembelajaran matematika siswa SD. Berikut ini adalah tabel hasil analisis uji Ancova.

Tabel 3. Hasil Analisis Data Menggunakan Uji Ancova

\begin{tabular}{lrrr}
\hline \multicolumn{4}{c}{ Descriptive Statistics } \\
\hline Dependent Variable: & Posttest & & N \\
\hline Model & Mean & Std. Deviation & 6 \\
\hline Jigsaw & 64,5083 & 17,59171 & 6 \\
TSTS & 74,5033 & 5,76486 & 12 \\
\hline Total & 69,5058 & 13,52845 & \\
\hline
\end{tabular}

Uji Ancova yang dilakukan pada model pembelajaran Jigsaw yang memiliki jumlah artikel sebanyak 6 dengan rata-rata 64,5083. Sedangkan pada model pembelajaran Two Stay Two Stray (TSTS) dengan jumlah artikel sebanyak 6 dengan rata-rata 74,5033. Sehingga model pembelajaran Jigsaw hasilnya lebih rendah dibandingkan model pembelajaran Two Stay Two Stray (TSTS). 
Tabel 4. Hasil Analisis Uji Ancova

\begin{tabular}{|c|c|c|c|c|c|c|}
\hline \multicolumn{7}{|c|}{ iable: PostTest } \\
\hline Source & $\begin{array}{l}\text { Type III Sum } \\
\text { of Squares }\end{array}$ & df & $\begin{array}{l}\text { Mean } \\
\text { Square }\end{array}$ & $\mathbf{F}$ & Sig. & $\begin{array}{l}\text { Partial Eta } \\
\text { Squared }\end{array}$ \\
\hline $\begin{array}{l}\text { Corrected } \\
\text { Model }\end{array}$ & $998,891^{a}$ & 2 & 499,446 & 9,694 &, 006 & ,683 \\
\hline Intercept & 604,029 & 1 & 604,029 & 11,724 & ,008 &, 566 \\
\hline PreTest & 560,991 & 1 & 560,991 & 10,889 & ,009 & ,547 \\
\hline BerpikirKritis & 304,890 & 1 & 304,890 & 5,918 & ,038 & 397 \\
\hline Error & 463,676 & 9 & 51,520 & & & \\
\hline Total & 48830,104 & 12 & & & & \\
\hline $\begin{array}{l}\text { Corrected } \\
\text { Total }\end{array}$ & 1462,567 & 11 & & & & \\
\hline
\end{tabular}

a. R Squared $=, 683$ (Adjusted R Squared $=, 613$ )

Berdasarkan hasil uji Ancova yang terletak pada kolom Berpikir Kritis di tabel 4, dapat disimpulkan bahwa signifikasi pada kolom Sig. sebesar 0,038. Fhitung yang diperoleh adalah 5,918 dan Ftabel adalah 4,26. Selanjutnya dilakukan uji hipotesis. Uji hipotesis dilakukan untuk menentukan apakah hipotesis penelitian ini diterima atau ditolak.

Berdasarkan hasil perhitungan hipotesis dengan menggunakan uji Ancova yang terdpat pada tabel 4 menggunakan Univariate yang menunjukan nilai signifikasi sebesar 0,038 yang artinya lebih kecil dari 0,05 $(0,038<0,05)$. Hasil uji Ancova membuktikan fhitung $<$ ftabel yaitu 5,918 > 4,26 dan signifikasinya 0,038 < 0,05 yang membuktikan bahwa Ho ditolak dan $\mathrm{Ha}$ diterima. Dari hasil tersebut terbukti bahwa terdapat perbedaan yang signifikan antara penggunaan model pembelajaran Jigsaw dan Two Stay Two Stray (TSTS) ditinjau dari peningkatan kemampuan berpikir kritis siswa sekolah dasar.

Tabel 5. Hasil Analisis Uji Ancova

\begin{tabular}{|c|c|c|c|c|c|c|}
\hline \multicolumn{7}{|c|}{ Dependent Variable: PostTest } \\
\hline Source & $\begin{array}{l}\text { Type III Sum } \\
\text { of Squares }\end{array}$ & df & $\begin{array}{l}\text { Mean } \\
\text { Square }\end{array}$ & $\mathbf{F}$ & Siq. & $\begin{array}{l}\text { Partial Eta } \\
\text { Squared }\end{array}$ \\
\hline $\begin{array}{l}\text { Corrected } \\
\text { Model }\end{array}$ & $998,891^{a}$ & 2 & 499,446 & 9,694 & ,006 & ,683 \\
\hline Intercept & 604,029 & 1 & 604,029 & 11,724 & ,008 &, 566 \\
\hline PreTest & 560,991 & 1 & 560,991 & 10,889 & ,009 &, 547 \\
\hline BerpikirKritis & 304,890 & 1 & 304,890 & 5,918 & 038 & 397 \\
\hline Error & 463,676 & 9 & 51,520 & & & \\
\hline Total & 48830,104 & 12 & & & & \\
\hline Corrected & 1462,567 & 11 & & & & \\
\hline
\end{tabular}

a. $\mathrm{R}$ Squared $=, 683$ (Adjusted R Squared $=, 613$ )

Setelah mengetahui hasil uji hipotesis yang membuktikan bahwa terdapat perbedaan yang signifikan antara penggunaan model pembelajaran Jigsaw dan Two Stay Two Stray (TSTS). Selanjutnya adalah menghitung Effect Size menggunakan uji Ancova pada tabel 5 menggunakan model pembelajaran Jigsaw dan Two Stay Two Stray (TSTS) terdapat hasil yang diketahui jika Partial Eta Squared sebesar 0,683 dengan nilai Sig. 0,006. Dapat disimpulkan model pembelajaran Jigsaw dan Two Stay Two Stray (TSTS) memberikan pengaruh tergolong besar terhadap kemampuan berpikir kritis pada pembelajaran matematika siswa sekolah dasar. Hal ini dipengaruhi oleh beberapa faktor.

Pertama, Model pembelajaran kooperatif tipe Jigsaw memberkan kesempatan pada siswa untuk mencari informasi dengan kelompok lainnya sehingga membuat pembelajaran 
menjadi menyenangkan (Rismawati, Rustono, \& Nugraha, 2017; T. Wardani \& Wiyasa, 2020). Hasil belajar siswa menjadi meningkat karena siswa dapat memaknai proses pembelajaran dengan baik. Model pembelajaran ini dapat meningkatkan hasil belajar pada siswa (Aminah, 2017; D. T. Wardani, 2015). Selain itu pembelajaran dengan penerapan model pembelajaran kooperatif tipe jigsaw dapat digunakan untuk melatih keterampilan kerja sama dan kolaborasi, serta juga keterampilan tanya jawab pada siswa. Model ini juga dapat meningkatkan rasa tanggung jawab pada siswa. Siswa tidak hanya mempelajari materi yang disampaikan oleh guru, tetapi siswa dituntut harus siap dalam memberikan serta mengajarkan materi tersebut pada kelompoknya. Sehingga siswa memiliki tanggung jawab terhadap dirinya sendiri dan juga kelompoknya. Model ini juga menuntut keaktifan pada siswa dengan dibentuk kelompok kecil yang beranggotakan 5-6 orang yang terdiri dari kelompok ahli dan asal.

Kedua, model pembelajaran Two Stay Two Stray (TSTS) membuat pembelajaran menjadi bermakna. Model pembelajaran ini memberikan kesempatan pada siswa (kelompoknya) untuk membagikan informasi ke kelompok lainnya. Model pembelajaran akan memberikan kesempatan pada siswa untuk menjawab, bertanya dan saling membantu teman (Anwar, 2018; Mulyantini et al., 2019). Kelebihan model pembelajaran Two Stay Two Stray yaitu 1) dapat diterapkan di semua kelas atau tingkatan, 2) meningkatkan keaktifan siswa, 3) membuat pembelajaran menjadi bermakna, 4) siswa akan berani mengungkapkan ide atau pendapatnya, 5) meningkatkan rasa percaya diri dan kekekompakan, 6) skill berbicara siswa meningkat, dan 7) meningkatkan minat dan prestasi belajar pada siswa (Dharsana \& Sidabutar, 2018; Sujana, Dharsana, \& Jayanta, 2018). Model pembelajaran ini memberikan pengalaman baru kepada siswa sehingga mampu meningkatkan pemahaman pada siswa. Model pembelajaran ini juga tidak berpusat pada guru melainkan siswa yan aktif untuk menggali pengetahuannya. Guru hanya bertindak sebagai fasilitator sehinga dapat meningkatkan kemampuan berpikir kritis pada siswa.

Dari dua model pembelajaran kooperatif tipe Jigsaw dan Two Stay Two Stray (TSTS) diasumsikan dapat meningkatkan kemampuan berpikir kritis siswa. Implikasi penelitian ini dapat digunakan sebagai salah satu referensi guru maupun peneliti selanjutnya yang akan menggunakan model pembelajaran Jigsaw dan Two Stay Two Stray (TSTS) terhadap kemampuan berpikir kritis pada pembelajaran matematika, agar siswa dapat menyelesaikan permasalahan yang diberikan oleh guru. Selain itu siswa dapat mengembangkan pola pikirnya untuk berpikir kritis dalam menyelesaikan sebuah permasalahan dan juga dapat menjalin sebuah kerjasama dengan temannya melalui tugas berkelompok. Kedua model tersebut memiliki perbedaan dalam aspek efektivitas, tetapi kedua model tersebut juga memiliki pengaruh dalam meningkatkan kemampuan berpikir kritis pada pembelajaran matematika.

\section{Simpulan}

Model pembelajaran Jigsaw dan Two Stay Two Stray (TSTS) memberikan pengaruh tergolong besar terhadap kemampuan berpikir kritis pada pembelajaran matematika siswa sekolah dasar. Model pembelajaran Two Stay Two Stray (TSTS) lebih efektif atau lebih berhasil jika dikomparasikan dengan model pembelajaran Jigsaw terhadap peningkatan kemampuan berpikir kritis pada pembelajaran matematika

\section{Daftar Pustaka}

Aminah, H. S. (2017). Meningkatkan Hasil Belajar IPA Melalui Model Kooperatif Tipe Jigsaw Berbantuan Media Gambar Kelas IV SD. Jurnal Pendidikan Progresif, 7(2), 93-100.

Andrian, \& Rusman. (2019). Implementasi Pembelajaran Abad 21 Dalam Kurikulum 2013. Jurnal Penelitian IImu Pendidikan, 12(1). https://doi.org/https://doi.org/10.21831/jpipfip.v12i1.20116. 14-23 
Anwar, M. (2018). Perbandingan Model Pembelajaran Kooperatif Tipe Jigsaw Dan Tipe Two Stay Two Stray Terhadap Kemampuan Berpikir Kritis Siswa Pada Materi Elastisitas. Jurnal Riset Fisika Edukasi Dan Sains, 5(2). https://doi.org/https://doi.org/10.22202/jrfes.2018.v5i2.2750

Ariawan, \& Pratiwi. (2017). Eksplorasi Kemampuan Siswa Kelas IV Sekolah Dasar Dalam Penyelesaian Soal Cerita Matematika. Jurnal Pendidikan Indonesia, 6(1), 82-95. Retrieved from https://ejournal.undiksha.ac.id/index.php/JPI/article/view/9184/6327. 82-95

Budiana, Sudana, \& Suwatra. (2013). Pengaruh Model Creative Problem Solving ( CPS ) Terhadap Kemampuan Berpikir Kritis Siswapada Mata Pelajaran IPA Siswa Kelas V SD. Mimbar PGSD Undiksha, https://doi.org/http://dx.doi.org/10.23887/jjpgsd.v111.816

Dadri, P. C. W., \& Putra, D. (2017). Pengaruh Model Pembelajaran Kooperatif Tipe Numbered Head Together (NHT) Terhadap Hasil Belajar Matematika Kelas IV. International Journal of Elementary Education, 5(2), 1-10. https://doi.org/http://dx.doi.org/10.23887/ijee.v3i2.18517

Dharsana, G. S., \& Sidabutar. (2018). Pengaruh Model Pembelajaran Kooperatif Tipe Two Stay Two Stray melalui Lesson Study terhadap Hasil Belajar IPA. MIMBAR PGSD Undiksha, 6(2). https://doi.org/http://dx.doi.org/10.23887/jjpgsd.v6i2.19463

Fatqurohman. (2010). Pemahaman Konsep Matematika Siswa dalam Menyelesaikan Masalah Bangun Datar. Jurnal IImiah Pendidikan Matematika, 4(2), 127-133. https://doi.org/10.25273/jipm.v4i2.847

Fitri, F. (2016). Peningkatan Kemandirian Mahasiswa Pendidikan Fisika Pada Mata Kuliah Mekanika Melalui Metode Reciprocal Teaching. Jurnal Pendidikan Fisika., 4(1). https://doi.org/http://dx.doi.org/10.24127/jpf.v4i1.391

Fuadi, H., Robbia, A. Z., Jamaluddin, J., \& Jufri, A. W. (2020). Analisis Faktor Penyebab Rendahnya Kemampuan Literasi Sains Peserta Didik. Jurnal IImiah Profesi Pendidikan, 5(2). https://doi.org/https://doi.org/10.29303/jipp.v5i2.122

Hurianti, B. F., \& Tastra, M. (2018). Penerapan Model Pembelajaran Kooperatif Tipe Numbered Head Together (NHT) Untuk Meningkatkan Kemampuan Siswa Dalam Menyelesaikan Soal Cerita Pada Mata Pelajaran Matematika Kelas V. Mimbar PGSD Undiksha, 6(1), 1-10. https://doi.org/http://dx.doi.org/10.23887/jjpgsd.v6i1.13107

Lubis, A. H. (2018). Integrasi TIK Dalam Pengajaran Bahasa Inggris Di Indonesia Abad Ke21: Mitos Dan Realita. Cakrawala Pendidikan, 37(1), 11-21. Retrieved from https://journal.uny.ac.id/index.php/cp/article/view/16738/pdf.

Mahendra, E. (2017). Project Based Learning Bermuatan Etnomatematika Dalam Pembelajar Matematika. Jurnal Pendidikan Indonesia, 6(1). https://doi.org/http://dx.doi.org/10.23887/jpi-undiksha.v6i1.9257

Mawarni, \& Muhtadi. (2017). Pengembangan Buku Digital Interaktif Mata kuliah Pengembangan Multimedia Pembelajaran Interaktif Untuk Mahasiswa Teknologi Pendidikan. Jurnal Inovasi Teknologi Pendidikan, 4(1). https://doi.org/https://doi.org/10.21831/jitp.v4i1.10114

Mulyantini, N. L. D., Suranata, K., \& Margunayasa, I. G. (2019). Pengaruh Model Pembelajaran Two Stay Two Stray Terhadap Minat Belajar Ipa Siswa Kelas IV SD. MIMBAR PGSD Undiksha, https://doi.org/http://dx.doi.org/10.23887/jjpgsd.v7i1.17023

Nurmiyati, \& Suyata. (2014). Keefektifan Paired Storytelling Dan Jigsaw Dalam Peningkatan Kompetensi Berbicara Siswa Kelas VIII SMP Negeri 3 Sleman. Jurnal Ling Tera, 1(2), 
210-223. https://doi.org/https://doi.org/10.21831/lt.v1i2.2597

Purwanti, S. (2015). Meningkatkan Kemampuan Komunikasi dan Berpikir Kritis Matematis Siswa Sekolah Dasar Dengan Model Missouri Mathematics Project (MMP). Jurnal Pendidikan Dan Pembelajaran Dasar, 2(2), 253-266.

Redhana, I. W. (2019). Mengembangkan Keterampilan Abad Ke-21 Dalam Pembelajaran Kimia. National Science Foundation Journal of Unnes, 13(1). Retrieved from https://journal.unnes.ac.id/nju/index.php/JIPK/article/view/17824

Rismawati, R., Rustono, \& Nugraha, A. (2017). Pengaruh Penggunaan Model Pembelajaran Kooperatif Tipe Jigsaw terhadap Hasil Belajar IPS Siswa Kelas IV di Sekolah Dasar. Jurnal IImiah Pendidikan Guru Sekolah Dasar, 4(2), 218-226.

Sari, M. K. (2014). Pengaruh Metode Kooperatif Jigsaw Terhadap Prestasi Belajar Mata Pelajaran IPS Pada Siswa Kelas III. Jurnal Pendidikan Dasar Dan Pembelajaran, 4(2), 113-144. https://doi.org/http://doi.org/10.25273/pe.v4i02.313

Sariani, N. W. (2020). Implementasi Program GLS Di SMP Negeri 1 Kuta Selatan Dalam Upaya Menumbuhkembangkan Minat Baca Siswa. Jurnal Pendidikan Kewarganegaraan, 8(1). https://doi.org/http://dx.doi.org/10.23887/jpku.v8i1.23949

Sujana, D. M. A., Dharsana, I. K., \& Jayanta, I. N. L. (2018). Pengaruh Model Pembelajaran Kooperatif Tipe Two Stay Two Stray melalui Lesson Study terhadap Hasil Belajar IPA. MIMBAR PGSD Undiksha, 6(2). https://doi.org/http://dx.doi.org/10.23887/jjpgsd.v6i2.19462

Wardani, D. T. (2015). Pengaruh Pembelajaran Kooperatif Tipe Stad (Student Teams Achievement Divisions) Dan Jigsaw Terhadap Prestasi Belajar Ekonomi Ditinjau Dari Motivasi Belajar Siswa Tahun Ajaran 2014/2015. EQUILIBRIUM: Jurnal IImiah Ekonomi Dan Pembelajarannya, 3(2), 105-112. https://doi.org/10.25273/equilibrium.v3i2.657

Wardani, T., \& Wiyasa, I. K. N. (2020). Pengaruh Model Pembelajaran Kooperatif Tipe Jigsaw Berbasis Catur Paramitha Terhadap Kompetensi Pengetahuan Matematika. Jurnal Pedagogi Dan Pembelajaran, 3(1), 25-33. https://doi.org/http://dx.doi.org/10.23887/jp2.v3i1.24358

Wicaksono, A. G. C., \& Corebima, A. D. (2015). Hubungan Antara Keterampilan Metakognitif Dan Retensi Siswa Dalam Strategi Pembelajaran Reciprocal Teaching Dipadu Jigsaw Dikelas X SMAN 7 Malang. BIOMA Jurnal Ilmiah Biologi, 4(1). https://doi.org/https://doi.org/10.26877/bioma.v4i1,\%20April.947

Witari, I. G. A., Putri, M., \& Rati. (2017). Pengaruh Model Pembelajaran Kooperatif Tipe Numbered Head Together Terhadap Hasil Belajar IPA Siswa Kelas IV. MIMBAR PGSD Undiksha, 5(2), 1-10. https://doi.org/http://dx.doi.org/10.23887/jjpgsd.v4i1.7445

Yokhebed. (2019). Profil Kompetensi Abad 21: Komunikasi, Kreativitas, Kolaborasi, Berpikir Kritis Pada Calon Guru Biologi Profile of 21st Century Competency: Communication, Creativity, Collaboration, Critical Thinking at Prospective Biology Teachers. BioPedagogi: Jurnal Pembelajaran Biologi, 8(2). Retrieved from https://jurnal.uns.ac.id/pdg/article/view/36154 